\title{
Effects of seed tuber size on the yield and quality of seven accessions of potato
}

\section{Md. Murad Hossan Chowdhury ${ }^{3},{ }$ Md. Amirul Islam ${ }^{1}$, Md. Atikuzzamman', Maria Akter Sathi ${ }^{2}$ and Sharmin Jahan ${ }^{2}$}

${ }^{1}$ International Maize and Wheat Improvement Center (CIMMYT), Bangladesh

${ }^{2}$ Department of Horticulture, Patuakhali Science and Technology University, Patuakhali, Bangladesh

${ }^{3}$ Department of Horticulture, Bangladesh Agricultural University, Mymensingh-2202, Bangladesh

\begin{tabular}{|c|c|}
\hline ARTICLE INFO ${ }_{\text {oPEN }}$ Access & Abstract \\
\hline $\begin{array}{l}\text { Article history: } \\
\text { Received : } 16 \text { May } 2019 \\
\text { Accepted : } 10 \text { June } 2019 \\
\text { Published: } 30 \text { June } 2019 \\
\end{array}$ & $\begin{array}{l}\text { A field experiment was carried out at the Horticulture Farm, Bangladesh Agricultural University, } \\
\text { Mymensingh during the period from November } 2011 \text { to February } 2012 \text { to study the effect of seed tuber } \\
\text { size on the yield and quality of seven accessions of potato. The experiment was laid out in the } \\
\text { Randomized Complete Block Design (RCBD) with three replications. This piece of research consisted of }\end{array}$ \\
\hline $\begin{array}{l}\text { Keywords: } \\
\text { Accessions quality, combined } \\
\text { effect, potato, seed size, yield }\end{array}$ & $\begin{array}{l}\text { two factors namely, size of seed tubers i.e. three different size of seed tuber i.e. small }(10-20 \mathrm{~g}) \text {, medium } \\
(21-30 \mathrm{~g}) \text { and large }(31-40 \mathrm{~g}) \text { and seven accessions of potato i.e. AC10064, AC10076, AC10097, } \\
\text { AC10109, AC10123, AC10190 and one check variety Cardinal. The size of individual plot was } 1.8 \mathrm{~m} \times \\
1.2 \mathrm{~m} \text {. Two adjacent unit plots and blocks were separated by } 0.5 \mathrm{~m} \text { and } 0.5 \mathrm{~m} \text {. A spacing of } 60 \mathrm{~cm} \times 30\end{array}$ \\
\hline $\begin{array}{l}\text { Correspondence: } \\
\text { Md. Amirul Islam } \\
\text { 凶: musa_amirul@yahoo.com }\end{array}$ & $\begin{array}{l}\mathrm{cm} \text { was also used in terms of planting. Data on different yield contributing characters and yield were } \\
\text { recorded. The tallest plants were produced by the large size of seed tuber accession AC10109 }(120.25 \mathrm{~cm}) \\
\text { which also took minimum time }(6.10 \text { days) to germinate and possessed maximum stem diameter }(0.95 \mathrm{~cm}) \\
\text { while small seed tuber of Cardinal required maximum days }(10.23 \text { days }) \text { along with shortest height }(60.22 \\
\mathrm{cm}) \text { as well as stem diameter }(0.65 \mathrm{~cm}) \text {. The large size seed tuber of accession AC10109 gave maximum } \\
\text { number of main stems/hill }(6.4) \text { and small size of seed tuber variety Cardinal gave minimum number of } \\
\text { main stems } / \text { hill }(2.96) \text {. The large size of seed tuber accession AC10109 produced maximum number of } \\
\text { compound leaves } / \text { hill }(64.80) \text { and the small size of seed tuber Cardinal produced minimum number of } \\
\text { compound leaves } / \text { hill }(35.74) \text {. In terms of yield character large size of seed tuber of AC10109 accession } \\
\text { exhibited highest results in tuber number } 9.60 \text { with the average diameter of tubers }(5.86 \mathrm{~cm}) \text { and yield was } \\
10.42 \mathrm{t} / \mathrm{ha} \text {. The accessions differed significantly with respect to all the plant characters studied. }\end{array}$ \\
\hline
\end{tabular}

Copyright:

(c) (7)

(92019 by authors and BAURES. This work is licensed under the Creative Commons Attribution International License (CC By 4.0).

\section{Introduction}

Potato (Solanum tuberosum L.) is regarded as a high potential food security crop in Bangladesh. It is a starchy, tuberous crop from the perennial of the Solanaceae family (also known as the nightshades). In Bangladesh, the cultivation of potato was widely started in the late $19^{\text {th }}$ century (Pushkarnath, 1969). It is the $3^{\text {rd }}$ most important crop of Bangladesh followed by rice and wheat which is commonly used as vegetables in Bangladesh. In 2017-18, it contributes to $3.13 \%$ of total crop production (acreage) in Bangladesh (BBS, 2019a). Potato varieties grown in Bangladesh may be divided into two groups namely, the local or indigenous and the high yielding or modern. The modern varieties of potato include those breed in the recent past, especially varieties introduced to Bangladesh after 1960 are designated as modern (Hashem, 1990). These varieties are characterized by relatively bigger tubers higher yield and fewer but thicker stems with bigger leaves (Rashid et al., 1987) and better responsive to applied inputs such as water, manures and fertilizers. However, with the introduction of modern potato varieties from Holland during the early sixties, the area and production of potato in Bangladesh began to increase rapidly and all of the new areas were covered by the modern varieties (Hashem, 1990). In the year 2017-2018, potato was grown in an area of $11,80,000$ acres and the production was $97,44,000$ metric tons (BBS, 2019b). The average yield comes to only 19.071 metric tons/ha. The potential yield of the crop is much higher than the average yield. Potatoes are commonly used in plant research. The consistent parenchyma tissue, the clonal nature of the plant and the low metabolic activity provide a very nice "model tissue" for experimentation. Despite of its huge importance in food industry like brew alcoholic beverages such as vodka, potcheen, or akvavit in worldwide; French fries and often hash browns in American restaurants; aloo ki sabzi, batata vada, chapatti, masala dosa and samosa in India etc., there are many reasons behind its yield reduction. Among the many causes of low yield of potato, lack of improved production technologies is very important. Seed quality, seed size, seed cutting, plant spacing etc. are some of the management practices which should be standardized for each agro-climatic zones of the country.

\section{Cite this article}

Chowdhury, M.M.H., Islam, M.A., Atikuzzamman, M., Sathi, M.A. and Jahan, S. 2019. Effects of seed tuber weight on the yield and quality of seven accessions of potato. Journal of Bangladesh Agricultural University, 17(1): 200-205. https://doi.org/10.3329/jbau.v17i2.41944 
The size of cut seed piece is important which influences the growth and yield of potato (Siddiqe et al., 1987). To optimize grower returns for specific markets, careful attention must be paid to cultural management practices that influence tuber size and other quality factors (Mckeown et al., 1990). The cost of potato production is very high, and the cost of seed potato it generally occupies nearly $40 \%$ of the total cost of production. But the size of cut tuber piece has not yet been well-defined to get the maximum yield and economic return. Under Bangladesh condition total number of eyes in a cut seed piece influences the number of shoot per hill and also the vegetative growth and foliage coverage, and ultimately the yield. Potato seed piece with spacing influences economically important characteristics, including total yield, marketable yield, tuber size distribution, and tuber quality (Love and Thompson, 1999).

Considering the above situation, the present work has been undertaken in order to characterize the important potato varieties and size of tubers in relation to their morphological characteristics, growth habit, yield and quality, using morphological traits with a view to investigating the relationship among the accession and selecting suitable ones for commercial cultivation under Bangladesh conditions.

\section{Materials and Methods Experimentation}

The research work was carried out during the period from November 2011 to February 2012 at the Horticulture Farm, Bangladesh Agricultural University, Mymensingh. The experiment was laid out in Randomized Complete Block Design (RCBD) with three replications. The experiment consisted of two factors namely, size of seed tubers and accessions. There were three different size of seed tuber i.e. small $(10-20 \mathrm{~g})$, medium $(21-30 \mathrm{~g})$ and large (31-40 g) and seven accessions of potato. First of all the entire experimental plot was divided into three blocks, each of which was then divided into 21 unit plots. As the experiment was replicated thrice the total number of plots was 63 . The treatment combinations were assigned randomly to the unit plots of each block. The size of unit plot was $1.8 \mathrm{~m} \times 1.2 \mathrm{~m}$. Two adjacent unit plots and blocks were separated by $0.5 \mathrm{~m}$ and $0.5 \mathrm{~m}$. A spacing of $60 \mathrm{~cm} \times 30 \mathrm{~cm}$ was used. The planting materials comprised the sprouted seed tubers of six improved exotic potato accessions i.e. AC10064, AC10076, AC10097, AC10109, AC10123, AC10190 and one check variety Cardinal. The potato accessions were collected from University of Wisconsion, USA. Seed was prepared by preheating and fanning in cold storage premises. They were kept in well-ventilated place where diffused light available for sprout initiation of tubers which led to planting. The well sprouted tubers were cut into three different sizes (small, medium, large) 24 hours before planting to get desired eye number. Production technique e.g. land preparation, manure and fertilizer application, planting seed tubers were followed the guidelines as stated in BARI handbook (Mondal et al., 2011). Intercultural operations i.e. weeding, mulching, irrigation, earthing up and plant protection were done as and when required. The crop was harvested at the sign of full maturity. Haulm cutting was also done at maturity level and after that the tubers were kept under the soil for skin hardening.

\section{Collection of data}

Data were recorded on different morphological parameters, yield components and yield from five randomly selected plants. The different parameters were days required for plant emergence, plant height at 30, 60 and 90 DAP (days after planting), number of main stems per hill, stems diameter at different DAP, number of compound leaves per hill, leaves length at different DAP, leaves breadth at different DAP, fresh weight of plant, number of tubers per hill, average length of tubers, average diameter of tubers from randomly selected tubers of each unit plot after harvesting and was expressed in centimeter, yield of tubers per hill were recorded which was converted per plot and per hectare.

\section{Qualitative characters}

Different qualitative character of tubers at horticultural maturity as stem color and shape, leaf color, outer and inner colour of tubers were recorded by visual estimation. The above mentioned parameters were observed keenly during data collection.

\section{Statistical analysis}

The collected data were compiled and analyzed using the Statistical, Mathematical Calculation and Data Management (MSTAT-C) package program. Morphological variation and yield performance among the varieties were studied by Analysis of Variance (ANOVA) by F-test. Relation of variables with the yield was studied using Pearson's Correlation Coefficient and Multiple Regression analysis. The significance of the difference between pairs of treatment means was evaluated by least significant difference (LSD) test at $5 \%$ level of probability (Gomez and Gomez, 1984).

\section{Results and Discussion}

The experiment was conducted to study the effect of different sizes of seed piece and different accessions/varieties with one check varieties of potato. It was conducted to determine the yield attributes of different accessions/varieties. Some of the data have been presented and expressed in table(s) and others in figures for ease of discussion, comparison and understanding. The results of each parameter have been discussed and possible interpretation where ever necessary has been given under following headings.

1. Effect of different size of seed tuber and accession on growth and yield contributing characteristics of potato 
Different parameters pertaining to yield and other yield contributing characters of potato as influenced by different size of seed tuber in relation to accession have been described below:

Plant emergence: Days required for plant emergence was significantly influenced by the combined effect of size of seed tuber and accession. Among the plant materials, the days required for plant emergence was minimum in AC10109 (6.10 days) with large size of seed tuber and maximum (10.23 days) time required to the small size of seed tuber of Cardinal (Table 1). Rashid et al. (1987) and Divis and Barta (2001) also didn't find significant relation of seed size and accessions to plant emergence but larger seed size gave maximum plants.

Table 1. Combined effect of different size of seed tuber and accessions on number of main stems, yield and yield contributing characters of potato

\begin{tabular}{|c|c|c|c|c|c|c|c|c|c|c|c|c|c|}
\hline \multirow[t]{2}{*}{$\begin{array}{c}\text { Size of } \\
\text { seed } \\
\text { tuber }(g)\end{array}$} & \multirow[t]{2}{*}{ Variety } & \multirow[t]{2}{*}{$\begin{array}{c}\text { Days } \\
\text { required for } \\
\text { emergence }\end{array}$} & \multirow[t]{2}{*}{$\begin{array}{c}\text { No. of } \\
\text { main } \\
\text { stem/hill }\end{array}$} & \multicolumn{3}{|c|}{$\begin{array}{c}\text { Stems diameter } \\
(\mathrm{cm}) \text { at different } \\
\text { DAP }\end{array}$} & \multirow{2}{*}{$\begin{array}{c}\text { Weight of } \\
\text { harvested } \\
\text { plant } \\
\text { (g/plant) }\end{array}$} & \multirow[t]{2}{*}{$\begin{array}{c}\text { No. of } \\
\text { tubers } \\
\text { /hill }\end{array}$} & \multirow{2}{*}{$\begin{array}{c}\text { Average } \\
\text { length of } \\
\text { tubers } \\
(\mathrm{cm}) \\
\end{array}$} & \multirow{2}{*}{$\begin{array}{c}\text { Average } \\
\text { diameter } \\
\text { of tubers } \\
(\mathrm{cm})\end{array}$} & \multirow[t]{2}{*}{$\begin{array}{c}\text { Yield of } \\
\text { tubers/ } \\
\text { hill (gm) }\end{array}$} & \multirow[t]{2}{*}{$\begin{array}{c}\text { Yield of } \\
\text { tubers/ } \\
\text { plot }(\mathrm{kg})\end{array}$} & \multirow[t]{2}{*}{$\begin{array}{l}\text { Total } \\
\text { yield } \\
\text { (t/ha) }\end{array}$} \\
\hline & & & & 30 & 60 & 90 & & & & & & & \\
\hline Small & $\mathrm{V}_{1}$ & 8.10 & 5.88 & 0.45 & 0.65 & 0.84 & 53.12 & 8.63 & 6.41 & 5.00 & 250.80 & 1.97 & 9.12 \\
\hline \multirow[t]{6}{*}{$(10-20)$} & $\mathrm{V}_{2}$ & 8.62 & 5.34 & 0.43 & 0.61 & 0.81 & 41.27 & 6.91 & 6.32 & 4.16 & 230.26 & 1.65 & 7.64 \\
\hline & $\mathrm{V}_{3}$ & 9.52 & 4.68 & 0.40 & 0.58 & 0.79 & 20.60 & 6.22 & 6.21 & 4.00 & 213.45 & 1.50 & 6.94 \\
\hline & $\mathrm{V}_{4}$ & 6.45 & 6.10 & 0.49 & 0.70 & 0.87 & 27.15 & 8.78 & 6.95 & 5.50 & 268.69 & 2.00 & 9.26 \\
\hline & $\mathrm{V}_{5}$ & 9.56 & 4.45 & 0.36 & 0.56 & 0.75 & 19.25 & 5.32 & 6.10 & 3.89 & 157.53 & 1.42 & 6.57 \\
\hline & $\mathrm{V}_{6}$ & 9.62 & 4.03 & 0.28 & 0.53 & 0.68 & 18.62 & 4.38 & 5.84 & 3.71 & 148.25 & 1.12 & 5.19 \\
\hline & $\mathrm{V}_{7}$ & 10.23 & 2.96 & 0.25 & 0.50 & 0.65 & 17.02 & 4.04 & 5.61 & 3.70 & 127.69 & 0.81 & 3.75 \\
\hline Medium & $\mathrm{V}_{1}$ & 8.03 & 6.05 & 0.48 & 0.67 & 0.87 & 55.20 & 9.05 & 6.50 & 5.14 & 253.60 & 2.06 & 9.54 \\
\hline \multirow[t]{6}{*}{$(21-30)$} & $\mathrm{V}_{2}$ & 8.49 & 5.42 & 0.47 & 0.65 & 0.85 & 42.33 & 7.02 & 6.42 & 4.40 & 231.40 & 1.70 & 7.87 \\
\hline & $\mathrm{V}_{3}$ & 9.05 & 5.05 & 0.42 & 0.63 & 0.82 & 21.45 & 6.40 & 6.35 & 4.10 & 215.36 & 1.53 & 7.08 \\
\hline & $\mathrm{V}_{4}$ & 6.20 & 6.25 & 0.51 & 0.72 & 0.90 & 27.85 & 9.17 & 7.10 & 5.75 & 270.15 & 2.10 & 9.72 \\
\hline & $\mathrm{V}_{5}$ & 9.15 & 4.50 & 0.38 & 0.60 & 0.80 & 20.35 & 5.55 & 6.24 & 4.00 & 160.04 & 1.47 & 6.81 \\
\hline & $\mathrm{V}_{6}$ & 9.41 & 4.12 & 0.30 & 0.59 & 0.72 & 19.00 & 4.88 & 6.00 & 3.95 & 150.42 & 1.16 & 5.37 \\
\hline & $\mathrm{V}_{7}$ & 10.00 & 3.02 & 0.28 & 0.53 & 0.67 & 17.91 & 4.16 & 5.89 & 3.84 & 129.79 & 0.88 & 4.07 \\
\hline Large & $\mathrm{V}_{1}$ & 7.95 & 6.13 & 0.53 & 0.70 & 0.91 & 56.00 & 9.20 & 6.70 & 5.24 & 262.46 & 2.21 & 10.23 \\
\hline \multirow[t]{6}{*}{$(31-40)$} & $\mathrm{V}_{2}$ & 8.31 & 5.60 & 0.52 & 0.69 & 0.90 & 43.67 & 7.20 & 6.56 & 4.50 & 239.46 & 1.77 & 8.19 \\
\hline & $\mathrm{V}_{3}$ & 8.92 & 5.10 & 0.52 & 0.68 & 0.89 & 23.32 & 6.80 & 6.50 & 4.38 & 218.20 & 1.59 & 7.36 \\
\hline & $\mathrm{V}_{4}$ & 6.10 & 6.40 & 0.53 & 0.76 & 0.95 & 29.00 & 9.60 & 7.30 & 5.86 & 285.40 & 2.25 & 10.42 \\
\hline & $\mathrm{V}_{5}$ & 9.04 & 4.60 & 0.48 & 0.66 & 0.82 & 22.00 & 5.60 & 6.30 & 4.32 & 169.56 & 1.50 & 6.94 \\
\hline & $\mathrm{V}_{6}$ & 9.34 & 4.20 & 0.32 & 0.66 & 0.76 & 19.32 & 5.00 & 6.10 & 4.10 & 162.46 & 1.18 & 5.46 \\
\hline & $\mathrm{V}_{7}$ & 9.85 & 3.06 & 0.30 & 0.56 & 0.71 & 18.00 & 4.40 & 6.06 & 3.90 & 132.86 & 0.92 & 4.26 \\
\hline LSD at $1 \%$ & & 0.156 & 0.140 & 0.099 & 0.121 & 0.099 & 0.197 & 1.154 & 0.121 & 0.140 & 4.997 & 0.099 & 0.452 \\
\hline $\begin{array}{l}\text { Level of } \\
\text { significance }\end{array}$ & & $* *$ & $* *$ & NS & NS & NS & $* *$ & $* *$ & $* *$ & $* *$ & $* *$ & $* *$ & $* *$ \\
\hline
\end{tabular}

$\mathrm{V}_{1}=\mathrm{AC} 10064, \mathrm{~V}_{2}=\mathrm{AC} 10076, \mathrm{~V}_{3}=\mathrm{AC} 10097, \mathrm{~V}_{4}=\mathrm{AC} 10109, \mathrm{~V}_{5}=\mathrm{AC} 10123, \mathrm{~V}_{6}=\mathrm{AC} 10190, \mathrm{~V}_{7}=\mathrm{Cardinal}$

$\mathrm{DAP}=$ Days After Planting, $\mathrm{LSD}=$ Least Significant Difference; $* *=$ Significant at $1 \%$ level of probability

Plant height: Plant height was recorded at different days after planting (DAP) and it was observed that different size of seed tuber significant variation in plant height at all the DAP. The large size of seed tuber accession AC10109 at 90 DAP showed maximum height (120.25 $\mathrm{cm})$ whereas the small size of seed tuber Cardinal at 90 DAP exhibited minimum $(60.22 \mathrm{~cm})$ (Fig. 1). Plant height showed a general trend of gradual increase with the increasing size of seed tuber at this stage of growth plant. The variation in plant height in this finding compared to findings of the present study may be due to difference in agro-ecological condition and soils of the experimental site. There was a statistically significant variation among rest of the accessions/varieties. This result was similar with an experiment conducted by Vinod et al. (2009).

Number of main stems per hill: The variation in number of stems per hill was found to be statistically significant among different size of seed tuber. The highest number of stems per hill (6.40) was found with the large size of seed tuber accession AC10109 which was statistically differed from other varieties. This result is similar with the experiment conducted by Schepers et al. (1984). Increase in seed size improved number of stems/hill (Vinod et al., 2009). The lowest number of stems per hill (2.96) was found Cardinal variety, which was statistically identical with the other varieties (Table 1).

Stem diameter: There was not significant variation among the potato accessions/varieties under trial in stem diameter at 90 DAP. The lowest $(0.65 \mathrm{~cm})$ stem diameter was found 90 DAP of small size of tuber in the variety Cardinal. On the other hand, medium and large size of tuber also gave highest stem diameter $0.90 \mathrm{~cm}$ and $0.95 \mathrm{~cm}$ respectively in the variety AC10109 (Table 1).

Number of compound leaves per hill: The number of compound leaves/hill varied significantly among the accessions/varieties studied at 30,60 and 90 DAP. The number of compound leaves/hill ranged from 35.74 to 64.80 among the different accessions/varieties at 90 DAP (Fig. 2). The maximum number of compound leaves/hill was produced by the large size of seed tuber accession AC10109 whereas minimum was observed in the small size of seed tuber variety Cardinal at 90 DAP (35.74). The varietal difference in number of compound leaf per hill might be due to difference in agroecological condition and soils of the experimental site. 


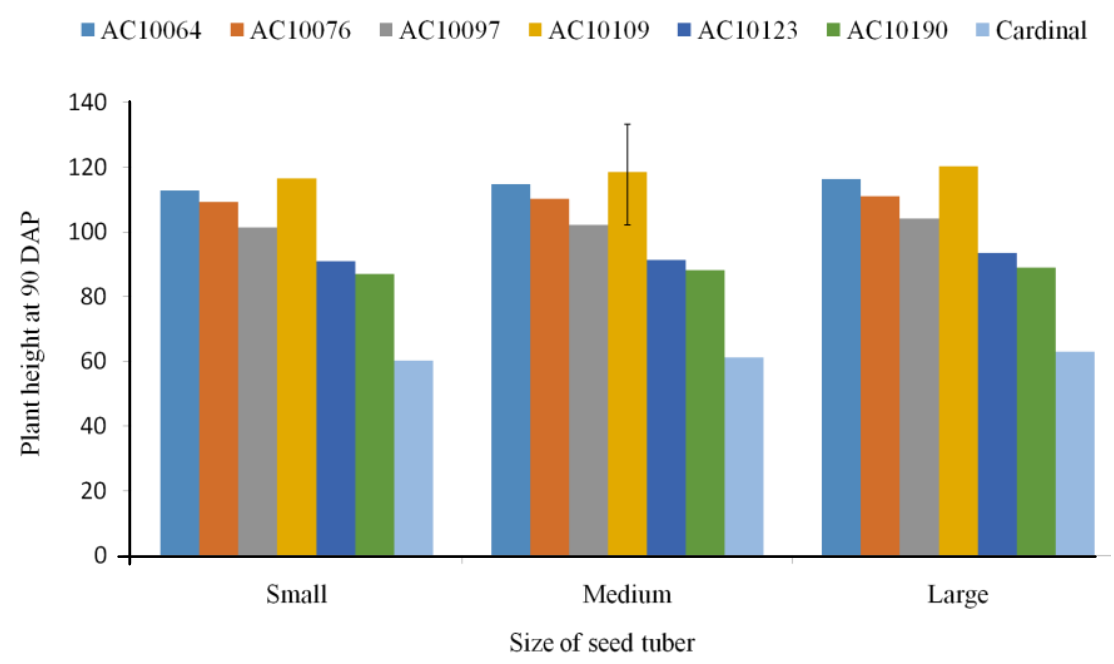

Fig. 1. Effects of size of seed tuber and accession on plant height at 90 DAP. Vertical bar represents LSD at $1 \%$ level of probability

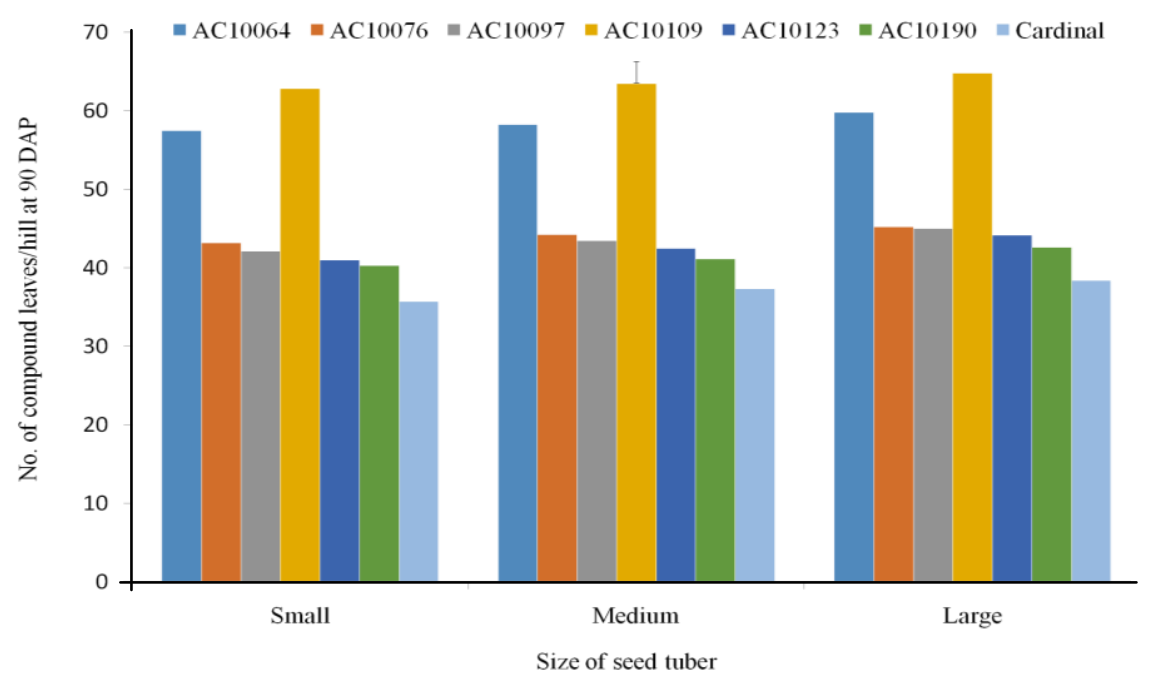

Fig. 2. Effects of size of seed tuber and accession on number of compound leaves per hill at 90 DAP. Vertical bar represents LSD at $1 \%$ level of probability

Weight of harvested plant: The results on combined effect of different varieties and size of seed tuber on the weight of harvested plant have been shown in (Table 1). Weight of plant was taken from the average of 5 plants selected randomly from each unit plot after harvesting. The maximum average weight of five plants was found at large size of seed tuber in the variety/accession AC10064 $(56.00 \mathrm{~g})$ followed by medium size of seed tuber $(55.20 \mathrm{~g})$ and small size of seed tuber $(53.12 \mathrm{~g})$ per plant. On the other hand minimum weight of five plants was found in Cardinal (17.02 g) followed by AC10190 (18.62g) per plant.

Number of tubers per hill: The number of tubers/hill varied significantly among the varieties/accessions under trial (Appendix II). The number was found to vary from 4.04 to 9.60. Among the accessions/varieties studied, the number of tubers/hill was found to be the largest in large size of seed tuber accession AC10109 (9.60) followed by large size of seed tuber accession AC10064 (9.20), medium size of seed tuber accession AC10109 (9.17) and medium size of seed tuber accession AC10064 (9.05). On the other hand the lowest number of tubers/hill was observed in small size of seed tuber Cardinal (4.04) followed by medium size of seed tuber Cardinal (4.16) and small size of seed tuber accession AC10190 (4.38) although they were statistically significant on number of tuber per hill basis (Table 1).

Average length and diameter of tubers per hill: There was significant variation among the potato accessions/varieties under trial in average length and diameter of tubers per hill. The maximum average length and diameter of tubers/hill (Table 1) was found in the large size of seed tuber accession AC10109 which are $7.30 \mathrm{~cm}$ and $5.86 \mathrm{~cm}$ followed by the medium size of seed tuber accession AC10109 i.e. $7.10 \mathrm{~cm}$ and $5.70 \mathrm{~cm}$ respectively. On the other hand minimum average length of tubers/hill was found in small size of seed tuber Cardinal $(5.61 \mathrm{~cm})$ followed by the medium size of seed 
tuber Cardinal $(5.89 \mathrm{~cm})$ whereas minimum average diameter was in small size of seed tuber Cardinal (3.70 $\mathrm{cm})$ followed by the small size of seed tuber accession AC10190 (3.71 cm).

Yield of tubers per hill: There was significant variation among the accessions/varieties under trial in yield of tubers per hill. The highest yield of tubers per hill was found in the large size of seed tuber accession AC10109 $(285.4 \mathrm{~g})$ followed by the medium size of seed tuber accession AC10109 (270.15 g) and small size of seed tuber accession AC10109 (268.69 g). On the other hand, the lowest yield of tubers per hill was found in small size of seed tuber Cardinal (127.69 g) (Table 1). The result is quite similar with Hussain (1992), Divis and Barta (2001) and Singh et al. (2003).

Yield per hectare: Total yield per hectare was highly significant among the different accessions/varieties combinations of size of seed tuber due to their combined effect. Among the accessions/varieties large size of seed tuber accession AC10109 (10.42 t/ha) was the high yielder. Accession AC10064 (10.23 t/ha) was closely related which is dissimilar with Zulker (2009). Small size of seed tuber variety Cardinal produced the minimum yield per hectare (3.75 t/ha) (Table 1$)$ which is contradict with Anam et al. (1980). The highest yield per hectare of the large size of seed tuber accession AC10109 might be due to proper physiological maturity of seed tubers and better adaptability of this accession under climatic condition of experimental site.

\section{Qualitative characters of different potato accessions}

Different qualitative characters of seven potato varieties/accessions were as follows: leaf color, stem color and tuber color (outer and inner). There was remarkable variation in different qualitative characters of potato. Leaf color was varied from light green to dark green in different potato varieties/accessions. The color of stem of seven varieties/accessions was light green to light violet. Tubers of seven varieties/accessions were round and elongated in shape. There was remarkable variation in tuber color (outer and inner) of potato varieties/accessions (Table 2 and Fig. 3).

Table 2. Variability in different qualitative characteristics in respect of leaf color, stem color, tuber color (outer and inner) of seven potato varieties/accessions

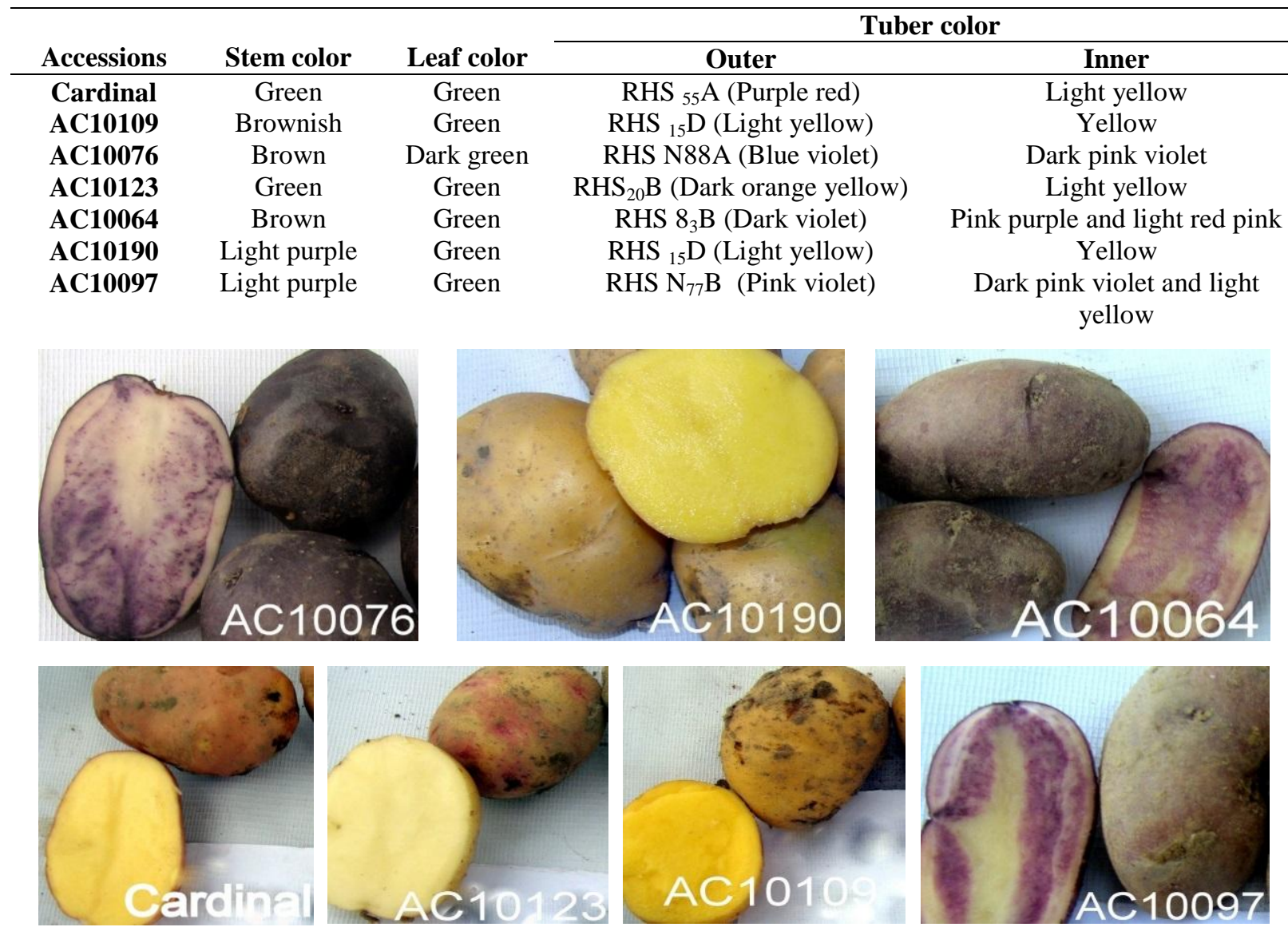

Fig. 3. Photograph showing the tubers outer and inner colour of different accessions of potato

\section{Conclusion}

Combined effect of different size of seed tubers and accession were also found as significant influential factors of quality, yield, number of main stem per hill, stem diameter, number of tubers per hill, average length of tubers, average diameter of tubers, yield of tuber per 
hill, leaves length, maximum leaves diameter, number of compound leaves per hill except stem diameter. The treatment combination of accession AC10109 with large size of seed tuber gave the highest yield of tuber per plot $(2.25 \mathrm{~kg})$ while the treatment combination of Cardinal with small size of seed tuber gave lowest yield of tuber per plot $(0.81 \mathrm{~kg})$. At 90 days after planting the highest plant height $(120.25 \mathrm{~cm})$, stem diameter $(0.95 \mathrm{~cm})$, leaves length and diameter $(17.00 \mathrm{~cm}$ and $7.40 \mathrm{~cm}$ respectively), and maximum number of compound leaves per hill (64.80) were observed in the treatment combination of accession AC10109 with large size of seed tuber. On the other hand the lowest yield of tuber per plot $(0.081 \mathrm{~kg})$. At 90 days after planting the lowest plant height $(60.22 \mathrm{~cm})$, stem diameter $(0.65 \mathrm{~cm})$, leaves length and diameter $(9.75 \mathrm{~cm}$ and $4.42 \mathrm{~cm}$ respectively), and minimum number of compound leaves per hill (35.74) were observed in the treatment combination of Cardinal with small size of seed tuber.

So, among different accessions, AC10109 performed better in yield and quality when it planted with large size of seed tuber. Most of the accession were able to show their yield potentiality even in the new environment of Bangladesh. A future study is also suggested to carry out in relation of seed size among other different accessions in Bangladesh to find the best result in terms of climate and yield.

\section{References}

Anam, K., Reza, M.A., Uddin, M., Khan, G., Roy, S. and Majid, A., 1980. Demostrative test of varieties in farmer's fields. Proc. $3^{\text {rd }}$ Workshop Potato Res. Workers. PRC, BARI, Joydebpur, Dhaka, pp.24-26.

BBS, 2019a. Year Book of Agricultural Statistics-2018. 30 ${ }^{\text {th }}$ Series. Bangladesh Bureau of Statistics, Statistics and Informatics Division (SID), Ministry of Planning, Government of the People's Republic of Bangladesh, pp. 34.

BBS, 2019b. Year Book of Agricultural Statistics-2018. 30 ${ }^{\text {th }}$ Series. Bangladesh Bureau of Statistics, Statistics and Informatics Division (SID), Ministry of Planning, Government of the People's Republic of Bangladesh, pp. xv.

Divis, J. and Barta, J., 2001. Influence of the seed-tuber size on yield and yield parameters in potatoes. Praha, Czech Republic: Ustav Zemedelskych a Potravinarskych Informaci. 47(6): 271-275.
Gomez, K.A. and Gomez, A.A., 1984. Statistical Procedure for Agricultural Research (2nd edition) International Rice Research Institute, A Willey International Science Publication, pp.28-192.

Hashem, A., 1990. An Introduction to the Potato Seed Industry of Bangladesh. In: Seed Potato in Bangladesh. Proc. Int. Seminar on Seed Potato. BADC, Dhaka, Bangladesh, pp.115 .

Hussain, M.M., 1992. Studies on production of seed potatoes in relation to variety and production practice. Ph.D thesis, Dept. of Horticulture, BAU Mymensingh. p.242.

Love, S.L. and Thompson J.A., 1999. Seed piece spacing influences yield, tuber size distribution, stem and tuber density, and net returns of three processing potato cultivars. Hort. Sci., 34: 629-633.

McKeown A.W., Coffin R.H., Yada R.Y. and Squire S., 1990. The concept and development of management profiles for potato cultivars and selections. Am. Potato J., 67: 527-535.

Mondal R.I., Islam, S., Bhuiyan, A.J., Rahman, M., Alam, M.S. and Rahman, M.H.H., 2011. Edited. KRISHI PROJUKTI HATBOI. (Handbook on Agro-Technology), $5^{\text {th }}$ edition. Bangladesh Agricultural Research Institute, Gazipur-1701, Bangladesh. Pp. 307-337.

Pushkarnath, 1969. Potato in India: Varieties. Indian Council of Agricultural Research, New Delhi, p.493.

Rashid, M.M., Rashid, M.H. and Sarkar, M.H., 1987. Yield Potential of Exotic Potato Varieties in Bangladesh. Res. Bull. PRC, BARI, Joydebpur, Gazipur. pp.1-11.

Schepers, A., Husiman, T. and Ridder, J.K., 1984. The effect of seed tuber sizes and plant population on the yield of seed potatoes. Bedrififs Ontiwikkeling, 15(3): 262-265. [Cited from Field Crop Abst., 11(3): 1986].

Siddique, M.A., Rabbani, M.G. and Azad, M.I., 1987. Effect of seed size, number of eyes in seed piece and plant spacing on the yield of potato. Bangladesh J. Agric., 1 2(2): 38-42, 73-81.

Singh, A.K., Yadav, V.K, Mir, M.S, and Khan, Z.H. 2003. Standardization of seed size and spacing for improving yield of potato (Solanum tuberosum L.) under cold arid condition of Ladakh. Calcutta, India: MKK Publication. 21(3): 639-641.

Vinod, K., Vyakarnahal, B. S. and Basavaraj, N., 2009. Effect of seed tuber size and dates of haulm killing on growth and yield of seed potato crop. Shimla, India: Indian Potato Association. 36(1/2): 45-50.

Zulker, A.B.M., 2009. A study on the performance of different USA Potato Lines. An M.Sc.Ag. Thesis, Department of Horticulture, Bangladesh Agricultural University, Mymensingh, pp.51-54. 